significance of positive ANCAs was not justified with the findings of the study, as the number of patients with positive ANCA was few.

\section{REFERENCES}

1 De Bandt M, Meyer O, Haim T, Kahn MF. Antineutrophil cytoplasmic antibodies in rheumatoid arthritis patients. Br J Rheumatol. 1996;35:38-43

2 Mustila A, Korpela M, Mustonen J, Helin H, et al. Perinuclear antineutrophil cytoplasmic antibody in rheumatoid arthritis. Arthritis Rheum. 1997;40(4):710-17

3 Coremans IEM, Hagen EC, Daha MR, et al. Antilactoferrin antibodies in patients with rheumatoid arthritis are associated with vasculitis. Arthritis Rheum. 1992;35 (12): $1466-75$

\section{THU0055 ROLE OF ANTIBODIES TO 5'NUCLEOTIDASE IN RHEUMATOID ARTHRITIS, SYSTEMIC LUPUS ERYTHEMATOSUS, SYSTEMIC SCLEROSIS, ANKYLOSING SPONDYLARTHRITIS AND REACTIVE ARTHRITIS PATIENTS}

AB Zborovsky, BV Zavodovsky, EV Bobicheva, LE Sivordova, NA Fofanova. Laboratory for Arthritis and Arthrosis, Research Institute for Clinical and Experimental Rheumatology, Volgograd, Russia

\subsection{6/annrheumdis-2001.899}

\section{Background}

Objectives Purpose of research was to study presence and role of definition of antibodies to 5'nucleotidase (anti-5NT) in rheumatoid arthritis (RA), systemic lupus erythematosus (SLE), systemic sclerosis (SS), ankylosing spondylarthritis (AS) and reactive arthritis (ReA) patients.

Methods There were 100 RA, 30 SLE, 20 SS, 30 AS and 20 ReA patients and 30 healthy donors (HD) under our observation. Anti-5NT were determined in serum of a blood with ELISA-test. We used 5'nucleotidase (AN 3.1.3.5) from Crotalus adamenteus venom («Sigma») as antigen.

Results We revealed, that the anti-5NT level in HD was equal $0,048 \pm 0,004$, in RA $-0,153 \pm 0,012$, in SLE - 0,101 \pm 0,016 , in SS $-0,117 \pm 0,017$, in AS $0,118 \pm 0,015$, in ReA $0,117 \pm 0,010$ (in all cases $\mathrm{p}<0.05$ ). We revealed difference between anti-5NT level in RA and SLE $(p<0,05)$, that can be used in differential diagnostics of these diseases. Was noted increasing of anti-5NT level in RA with muscles injury (without myositis $-0,150 \pm 0,013$, with myositis $-0,190 \pm 0,002)$ and kidney manifestations (without nephropathy $-0,149 \pm 0,013$, with nephropathy $-0,205 \pm 0,013)$. Taking into account that kidney injury in RA associates with perinuclear antineutrophil cytoplasmic antibody, we assume presence of cross reactions between them and anti-5NT.

Conclusion Thus, we revealed the new group of autoantibodies. The determination of them can improve diagnostics and differential diagnostics and better understanding of rheumatic diseases pathogenesis.

\section{REFERENCE}

1 Mustila A, Korpela M, Mustonen J, et al. Perinuclear antineutrophil cytoplasmic antibody in rheumatoid arthritis: a marker of severe disease with associated nephropathy. Arthritis Rheum. 1997;40(4):710-17
Background Kawasaki disease (KD) is an acute systemic vasculitis that primarily affects infants and young children below 5 years old. The cause of $\mathrm{KD}$ is still unknown, but the acute phase of $\mathrm{KD}$ is often accompanied by the alteration of circulating immune cells. The polyclonal activation of $\mathrm{B}$ cells during the course of disease is well documented.

Objectives In this study, the evidence of B cell activation and the possible involvement of superantigen in $\mathrm{KD}$ were sought.

Methods

Results In 13 out of $15 \mathrm{KD}$ patients, an increase in B cells expressing the $\mathrm{VH} 3$ family was seen during the acute phase of disease. Analysis of B cell clonal expansion showed the VH6 family clone of 9 amino acids to be the most common, observed in 5 out of $15 \mathrm{KD}$ patients. Analysis of CDR3 size profile showed that various prominent bands appeared during the acute phase of disease, and some disappearing during the subacute phase, while other newly developed bands appeared during the subacute phase of disease. The DNA sequences of CDR3s showed no dominant clone.

Conclusion These data suggest that KD may be caused by conventional antigen (s).

\section{THU0057 DISTURBED PERIPHERAL B CELL HOMEOSTAIS IN SLE}

${ }^{1} \mathrm{~T}$ Dörner, ${ }^{2} \mathrm{M}$ Odendahl, ${ }^{1} \mathrm{~A}$ Jacobi, ${ }^{1} \mathrm{~A}$ Hansen, ${ }^{1} \mathrm{~F}$ Hiepe, ${ }^{1} \mathrm{GR}$ Burmester, ${ }^{3} \mathrm{PE}$ Lipsky, ${ }^{2} \mathrm{~A}$ Radbruch. 'Department Medicine, Charite, Berlin, Germany; ${ }^{2}$ Deutsches Rheumaforschungszentrum, Charite, Berlin, Germany; ${ }^{3}$ NIAMS, NIH, Bethesda, MD, USA

\subsection{6/annrheumdis-2001.901}

Background The distribution of peripheral B cell subpopulations in SLE is unknown, although a variety of humoral abnormalities are known.

Objectives The phenotype and Ig heavy chain gene usage of peripheral B cell subpopulations of patients with active systemic lupus erythematosus (SLE) were examined.

Methods Peripheral B cells were characterised by FACS analysis and $\mathrm{B}$ cell subpopulations of one patient were characterised for $\mathrm{V}(\mathrm{D}) \mathrm{J}$ gene rearrangements.

Results In patients with SLE, there was a marked B lymphocytopenia that affected $\mathrm{CD} 19^{+} / \mathrm{CD} 27$ - naïve $\mathrm{B}$ cells more than $\mathrm{CD} 19^{+} / \mathrm{CD} 27^{+}$memory $\mathrm{B}$ cells leading to a relative predominance of CD27 expressing peripheral B cells. In contrast, CD27high/CD38 ${ }^{+} / \mathrm{CD} 19 \mathrm{dim} /$ surface Iglow/CD20-/syndecan-1 + plasma cells were found at an enhanced frequency in active but not inactive SLE patients. Upon immunosuppressive therapy, CD27high plasma cells and naïve CD27- B cells were markedly decreased in the peripheral blood. Mutational analysis of $\mathrm{V}$ gene rearrangements of individual B cells confirmed that $\mathrm{CD} 27^{+} \mathrm{B}$ cells coexpressing $\mathrm{IgD}$ were memory B cells preferentially using VH3 family members with multiple somatic mutations. CD27high plasma cells showed a similar degree of somatic hypermutation, but preferentially employed $\mathrm{VH} 4$ family members.

Conclusion These results indicate that there are profound abnormalities in the various B cell compartments in SLE that respond differently to immunosuppressive therapy.

\title{
THU0056 EVIDENCE OF B CELL ACTIVATION IN KAWASAKI DISEASE
}

